\title{
Concepts and Theories of Happiness of Population in Urban Neighbourhoods
}

\author{
Yusfida Ayu Abdullah 1*, Farrah Lyana Zulkifli ${ }^{2}$ \\ ${ }^{1}$ Centre of Studies for Town and Regional Planning, Faculty of Architecture, Planning and Surveying, 40450 UiTM Shah Alam, Selangor, Malaysia \\ ${ }^{2}$ Centre of Postgraduate Studies, Faculty of Architecture, Planning and Surveying, 40450 UiTM Shah Alam, Selangor, Malaysia
}

\begin{abstract}
In this paper, we impart on the notion of happiness and indicate the many beliefs and perspectives of happiness. The theory and concept of happiness are variously defined and interpreted by separate groups. It relates greatly to human's emotions thus influential in affecting the people's well-being. Most scholars often felt that happiness relates to wealth and health. Inevitably, the sentiment of happiness can be inspired by the surrounding environment and neighbourhood, facilities, family relationship, community and friends, and so forth. For this reason, it is important to uncover the perennial question of what constitute happiness within an urban neighbourhood.
\end{abstract}

(c) 2016. The Authors. Published for AMER ABRA by e-International Publishing House, Ltd., UK. Peer-review under responsibility of AMER (Association of Malaysian Environment-Behaviour Researchers), ABRA (Association of Behavioural Researchers on Asians) and cE-Bs (Centre for Environment-Behaviour Studies, Faculty of Architecture, Planning \& Surveying, Universiti Teknologi MARA, Malaysia.

Keywords: Happiness; happiness theory; urban neighbourhood

\section{Introduction}

People living in cities and urban areas are always linked to a low happiness level or low satisfaction on living conditions. Happiness Index or other types of similar measurements have been a new focus of governments and people around the world. Various studies have been carried out at the national and city levels (Bartolini et al., 2013; Florida et al., 2013; Frey and Stutzer, 2013; Tandoc and Takashi, 2013). However, most studies were not focused on the living environment or neighbourhood (Bergsma et al., 2010; Moradi et al., 2013; Snoep, 2008; Spruk \& Keseljevic, 2014). Additionally, the application of happiness theory for the Malaysian urban neighbourhood environment is yet undecided. Therefore, this paper intends to grasp the happiness theory that can potentially relate to the Malaysian urban neighbourhood environment hence filling the gaps of previous happiness studies.

Regrettably, the suicide rate in Malaysia is on the rise, with more than 1,000 people taking their lives over a three-year period. This shows that many people are not happy, and it might affect their mental health and ability to face the challenges in life. The Prime Minister of Malaysia stresses that the government cannot rely on the statistics alone but need to understand the people's feeling (The Star, 2013). In line with the government's commitment to place the citizen first instead of performance, urban

\footnotetext{
${ }^{*}$ Corresponding author. Tel.: +6 035544 4343; fax: +6 0355444353.

E-mail address: yusfida@salam.uitm.edu.my.
}

(C) 2016. The Authors. Published for AMER ABRA by e-International Publishing House, Ltd., UK. Peer-review under responsibility of AMER (Association of Malaysian Environment-Behaviour Researchers), ABRA (Association of Behavioural Researchers on Asians) and cE-Bs (Centre for EnvironmentBehaviour Studies, Faculty of Architecture, Planning \& Surveying, Universiti Teknologi MARA, Malaysia.

DOI: $h$ ttp://dx.doi.org/10.21834/e-bpj.v111.222 
development should, therefore, consider promoting a high level of happiness among the people. Encouragingly, the government currently applies some indexes to measure wellbeing such as The Malaysian Quality of Life and the Happiness and Family Wellbeing Index. However, both frameworks only focus on certain aspects and are inadequate (Bernama, 2013).

\section{The Definition of Happiness}

Happiness is differently defined and interpreted by a philosopher, researcher, academician, politician or a housewife. Aristotle believed that happiness or "Eudaimonia" is the uppermost human joy achieved through wellbeing or contentment. He argued that happiness is an action that depicts one's virtue (Kenny, 2014). According to Gavin and Mason (2004), happiness is obtained when all of his or her wishes is accomplished throughout the life period. A variety of incidents can make us happy and the experience of this feeling varies from time to time. For example, going to the theme park with friends is exciting, drinking lemonade under the hot weather is refreshing and giving birth to a child is emotionally uprising. Therefore, it can be suggested that happiness can occur and flourish from different angles. Sometimes it can be seen as a "subjective wellbeing" depending on the individuals' experience or disposition (Diener and Biswas-Diener, 2009; Wirtz and Diener, 2004).

Happy people are seeing smiling during social interactions and are rated as happy by friends and family members. When happiness is deemed subjective, it reflects through wealth, power, status, security, job or even by good relationships with family, friends, neighbours and colleagues (Frey and Stutzer, 1999).

\subsection{The importance of happiness}

Happy people tend to fall sick less than unhappy people. Unhappy people can potentially lead to mental disorders namely depression, anxiety and hostility and causes damaging consequences in the long run like a lower immune response and high blood pressure. People who are happy will be more weight cautious, do more sports, reduce smoking and drinking and be more alert with illness symptoms. Significant and positive links have been found between self-declared happiness and healthy physical reactions such as smiling attitudes and heart rate and blood pressure responses to stress (Becchetti, Pelloni, and Rossetti, 2007).

In our everyday lives, we do activities whether it associates with other people or the opposite. We work, communicate, eat, play, leisure and many more. But most important of all, it brings positive energy and makes others feel comfortable, glad and delighted to be around us. Across the globe, people are working hard to attain a good quality of life. However, working requires time, energy, mind and also feelings and will eventually cause stress. The effects spill out the negative emotions on others, their family, friends and people around them. A recent survey on British workers regarding job stress discovered that eight million workers complained that the pressure at work gave them headaches and twelve million said that they get bad-tempered and irritable at home. Healthy and happy workers will be more productive in the long run and give more fulfilling services to their clients and to whomever they interact while working. It is stated that the three things - happiness, health and productivity are the essential ingredients of a good society (Gavin and Mason, 2004).

\subsection{The elements of happiness}

It is suggested that a person with high subjective well-being is someone who holds joy and affection along with only occasional negative effects like guilt or anger, yet experiences satisfaction. Therefore, happiness consists of several elements and when being put into a formula, develop the most called term by researchers to indicate happiness as the Subjective Wellbeing (SWB). The formula below illustrates:

$$
\text { "Subjective Wellbeing = Positive Affect - Negative Affect + Life Satisfaction + Flourishing" }
$$

\section{- Emotion}

(Diener and Biswas-Diener, 2009)

The SWB includes all of the positive emotions ranging from joy to affection and gratitude. However, when there is positive, there will be negative too which makes a complete balance. Hence, it is similar to the SWB formula whereby unpleasant emotions is included. The reason behind this is because that even the most cheerful person has ups and downs in experiencing their lives.

- Life satisfaction 
Another suggested cognitive element to wellbeing was life satisfaction. It is the act of people assessing and perceive how they are doing in life. For example, a person is delighted to own a brand new car while another would not be bothered since he could not afford one.

\section{- Flourishing}

Flourishing describes the circumstance where a person has positive evaluations on all of the important aspects of life namely relationship, health, work and many more. People sometimes turn down or sacrifice one element to another suggesting a tradeoff for happiness. By this, people commonly turn down offers to participate in emotionally rewarding activities in the present so that they can continue to work toward goals that will reap larger psychological rewards in the future.

\section{The Theory of Happiness}

Besides the various definitions of happiness, there are also many theories on happiness. The Theory of Hedonism psychologically stands for seeking for pleasure. Nevertheless, there is also the asceticism that rejects pleasure and selfless behaviour (Veenhoven, 2003). It expands pleasure and diminishes pain. Hedonism can, therefore, be seen in the modern days through the Hollywood entertainment (Seligman and Royzman, 2003).

Another theory called the Theory of Desire demonstrates the urge of wanting something and it may end either with satisfaction or frustration. It is normal behaviour experienced by most people. The Desire Theory can be seen from a girl longing for gold earrings, a man wishing for more income or a boy wanting to be a football star. It is a theory that describes the feeling of yearning and the actions taken to acquire the wish (Schroeder, 2006).

The Objective Theory provides a list of things and activities that are considered to be good for a person and are called objective list theories of wellbeing. It comprises of moral goodness, rational activity, the development of one's abilities or being a good parent. This objective theory perceives that life is good for the person who is living it (Varelius, 2013).

Apart from that, the Authentic Happiness Theory embraces all of the three traditional theories above. It satisfies the three theories mentioned before. The theory is believed as the "Full Life" when Hedonism is called the "Pleasant Life"; the Desire as a "Good Life" and Objective List as a "Meaningful Life" (Seligman \& Royzman, 2003).

\subsection{Philosophical and religious beliefs}

Apparently, happiness is not just about emotion and feeling but has an interesting background to it. It is also inspired by the many religious notions and the beliefs of philosophers. Lehrer (2004) claimed that religion helps people physically and mentally. Past studies discovered that religious people have higher subjective well-being than the non-religious individuals. Religion prevents a person to be aimless in life, dishonoured and feeling lonely. It was reported that people who live in hunger and poverty in the underprivileged nations are highly religious that people who live in flourished nations (Diener, Tay, \& Myers, 2011). A research studying the relationship between religion and happiness in Netherlands, Denmark and United States of America showed a remarkable result. The result of the research suggested that the effect of religious is clearer on a specific group. The strongest predictor of happiness in the USA is the "the time spend with people at church". Meanwhile in the Netherlands and Denmark, "belong to a church organisation" is the most pivotal (Snoep, 2008). Therefore, the effects of religion are not the same to everyone and everywhere around the world. It could be positive or negative effects.

\section{- The Greek philosophers}

The Greek philosophers believe that happiness is derived from three defining characteristics that are freedom, knowledge and virtue. Freedom is when people can think independently and choose freely. By this, they are considered happy as they are not under control or restrictions in expressing themselves. Happy people possess knowledge where they have the information and ability in reasoning. Virtue conversely is moral characters and ethics (Gavin \& Mason, 2004). Unfortunately, in this millennium era, economics and financials are seen to be more valuable.

\section{- Al-Farabi the Islam philosopher}

Al-Farabi (870-950 C) believes that man is created to achieve the highest happiness called the "saadah" in Arabic. Farabi's view on happiness is more religious where he believes that the achievement of happiness is both for the world and the life after death. He believes that education could create an ideal community that would then bring all cities together in achieving 
happiness (Hamedi, 2013). He claimed that material possession will not guarantee one's happiness as the final happiness will be achieved in the next world (Voegelin, 2009).

\section{- The ancient Chinese philosophers}

As described by Guoging Zhang and Veenhoven (2008), Confucius (551-472 B.C) had asked his followers to possess virtues through knowledge. He believed that the people's quality of life is closely affected by their government and that the devotees should actively be involved in the society. The belief does not focus on individualistic but the community as a whole. Lao Tzu, another Chinese philosopher, had founded the Taoism in the sixth century B.C. However, this philosophy is the opposite of Confucianism and is rather individualistic. Taoism thinks that the people should take care of nature. It demands the people to focus more on personal living rather than social. The values of duties and other social ties are considered as inessential. Another philosopher, Buddha Gautama (560-480 B.C), who founded the Buddhism, believes that any incidents are interconnected with each other. The Buddhists believe in the three concepts namely Karma, Samsara and Nirvana and suggest happiness through meditating.

\subsection{The factors of happiness}

In addition to the effect of religious and philosophers' beliefs, happiness is affected by many other factors too. It is imperative to value these factors in trying to develop a happiness theory framework. Ott (2006) identifies the list labelled as the "Big Seven" by Layard (2005) as follow:

\section{- Work}

Employment provides services and sustains people in everyday lives. People are reported to be a lot happier when they have secured jobs. Losing a job affects one's level of happiness (Leyden, Goldberg and Michelbach, 2011). Field (2009) claimed that unemployment is the root of stresses and problems in families, communities and individuals. Hence, commercial activities within neighbourhood areas help to reduce the problem of unemployment.

\section{- Personal freedom}

Personal freedom refers to the governance and individual right. It is the quality of a social system (Veenhoven, 2007) that stimulates happiness. A research conducted in China investigating governance effectiveness discovered the importance of government's responsibility in affecting people's happiness (Han, 2015). In this sense, the security of private property is important to create the feeling of personal freedom, therefore, providing safety within the community and neighbourhood. Thus, the neighbourhood design can also influence the personal freedom and happiness of the community.

\section{- Personal value}

The personal value may consist of elements like family, friends, job security, trust and religion. As Lehrer (2004) quotes Snoep (2008), religion has a positive effect on happiness. However, the importance of religion varies in different societies (Diener et al., 2011). Countries that are poorer may find that religion helps them to make happy instead of wealth. Malaysia is seen as a country of multi-racial with various religions being embraced. Like so, neighbourhood areas should cater the spiritual needs of its residents with the development of various religion institutions.

\section{- Community and friends}

People are happier living within a community that can be trusted and when actively participate in community activities together (Leyden et al., 2011). Helliwell and Putnam (2005) proved that happiness is significantly related to spending time with friends and neighbours, civic participation, and trust in neighbourhoods. This interaction is known as the social support networks and can contribute to the wellbeing of the population.

\section{- Family relationships}

DeFrain, Brand, Friesen, and Swanson (2008) claimed that families develop the human society. Family is a fundamental social component. Through this constituent, people obtain love, security and warmth. Family is deemed to be significant in social institutions. In fact, it is seen to be central to Islam (Benharoon, 2013). In Islam, this concept is called halaqah.

- Health 
An active lifestyle can reduce many diseases such as heart disease, stroke and obesity. A Canadian study found that being physically active will reduce the chance of being unhappy to 15 percent (Douglas, 2013). Macdonald (2005) feels that the living environment is also important in influencing people's. Additionally, good design and people-friendly spaces and places can promote active lifestyles (Healthy Spaces and Place Manual, 2009).

- Financial situation

There is a positive relationship between personal income or wealth and happiness. Increased in income level has been the factor of happiness especially in the western countries (Borrero, Escobar, Cortes, and Maya, 2013). However, the negative relationship between wealth and happiness level was argued by the Easterlin Paradox. It was stated that the increased in wealth in the USA since the 1950s had not come along well with the increased of happiness. The increased of wealth in Japan and South Korea had caused the citizens to feel less happy too. This brings to a suggestion that economic growth may bring both positive and negative effects (Veenhoven and Hagerty, 2006).

\section{The Concept of Urban Neighbourhood}

The definition of an urban neighbourhood is covered entirely by the definition of the neighbourhood itself. The word neighbourhood describes urban or rural areas and comprises of communities (Meenakshi, 2011). Neighbourhood areas are thought to be lively and that they continuously develop. It should cater its people with economic, social and psychological benefits. Neighbourhoods are shaped by many aspects and influenced by cultures, histories, wealth and poverty, migrations, as well as government policy (Cox et al., 2013).

\subsection{Neighbourhood environment}

The neighbourhood environment plays a crucial role in a person's life. Neighbourhood issues such as lack of facilities, noise, pollution and crime may affect the people's health. A neighbourhood environment can be divided into three major features; the physical, social and service environments. The physical environment is the structures and buildings. Social environment, on the other hand, is the relationship developed among residents such as honesty, trust and cooperation. Meanwhile, service environment is the resources like institutions, transportation, recreational area and many others. A research in Scotland and England revealed that a poor living environment had deteriorated health condition. Another study in New Zealand discovered that neighbourhood environment had caused obesity among the people (Pearson, Bentham, Day and Kingham, 2014).

\subsection{Neighbourhood and community}

The community is made up of a cluster of people with common geographical settings (Green and Mercer, 2001). The Canadian Institute of Advanced Research found that people in a small scale community are happier because of the quality of social relationships. It is also reported that socially isolated people has the equal level of happiness as poor people and politically unstable countries (Omand, 2015). Therefore, social interactions within a community are considerable important for happiness. Nowadays, a sustainable community has been the talk of researchers, urban planners, politicians, architects and many other professions. The issues of sustainable communities are seen to be interconnected with neighbourhood planning aspects. Thus, sustainable community can be considered as influential in elevating happiness. Table 1 below suggests the components for a sustainable neighbourhood. 
Table 1. The components of a neighbourhood

\begin{tabular}{|c|c|c|c|}
\hline Neighbourhood Envirol & & Planning Elements & $\begin{array}{l}\text { Community } \\
\text { Characteristics }\end{array}$ \\
\hline \multirow{18}{*}{ Physical Environment } & Housing & Terrace House & \multirow{18}{*}{$\begin{array}{l}\text { Identity } \\
\text { Linkages }\end{array}$} \\
\hline & \multirow{4}{*}{$\begin{array}{l}\text { Mixed types of houses that integrates ranges } \\
\text { of age, income and household sizes }\end{array}$} & Semi-detached house & \\
\hline & & Apartments & \\
\hline & & Condominium & \\
\hline & & Flats & \\
\hline & Buildings & & \\
\hline & Accommodate different needs over time & Community Centre & \\
\hline & Infrastructure & Bus stop & \\
\hline & \multirow{2}{*}{$\begin{array}{l}\text { Public transport and infrastructures that link } \\
\text { the community with city, rural, etc. }\end{array}$} & Train & \\
\hline & & Taxi & \\
\hline & Layout & Residential zoning & \\
\hline & \multirow{4}{*}{$\begin{array}{l}\text { The size, scale and density of layout that } \\
\text { accommodates people with amenities and } \\
\text { diminish use of resources }\end{array}$} & Commercial zoning & \\
\hline & & Social facilities & \\
\hline & & Open space & \\
\hline & & Layout design & \\
\hline & Safe and Healthy Environment & Recreational area & \\
\hline & \multirow[t]{2}{*}{$\begin{array}{l}\text { Provision of green space and well-designed } \\
\text { area }\end{array}$} & $\begin{array}{l}\text { Soft and hard } \\
\text { landscape }\end{array}$ & \\
\hline & & Guard post & \\
\hline \multirow{8}{*}{ Service Environment } & Public Service & Religion institutions & \multirow{15}{*}{$\begin{array}{l}\text { Integration } \\
\text { Group orientation }\end{array}$} \\
\hline & \multirow{3}{*}{$\begin{array}{l}\text { Good quality of public service like community } \\
\text { facilities, recreational area etc }\end{array}$} & Educational institutions & \\
\hline & & Recreational area & \\
\hline & & Community Centre & \\
\hline & Economy & Shops & \\
\hline & \multirow{3}{*}{$\begin{array}{l}\text { Flourished economy that provides jobs and } \\
\text { revenues }\end{array}$} & Grocers & \\
\hline & & Night market & \\
\hline & & Stalls & \\
\hline \multirow{7}{*}{ Social Environment } & Public Participation & & \\
\hline & $\begin{array}{l}\text { Participation and engagement by the local } \\
\text { people }\end{array}$ & Community Centre & \\
\hline & Leadership & \multirow{2}{*}{$\begin{array}{l}\text { Parks and recreational } \\
\text { area } \\
\text { Shops }\end{array}$} & \\
\hline & $\begin{array}{l}\text { Good leadership to enable positive attitudes } \\
\text { toward changes }\end{array}$ & & \\
\hline & Community & Library & \\
\hline & $\begin{array}{l}\text { Having pride with community through vibrant } \\
\text { and diverse local cultures }\end{array}$ & \multirow[t]{2}{*}{ Museum } & \\
\hline & Sense of place & & \\
\hline
\end{tabular}




\section{The Link Between Happiness and Neighbourhood}

An earlier discussion had demonstrated that happiness and neighbourhood planning are very much interrelated. Aristotle's belief in good life mentioned that virtue can be accomplished through good planning of the social environment, comprising of leadership and community. Meanwhile, the principles of Al-Farabi that emphasises the importance of the knowledge to create good communities and this can be achieved through well-planned service environment. Other than that, the components of a sustainable community, as shown in Table 1, can, therefore, lead to happiness. Figure 1 below shows the link between the elements. However, a neighbourhood may not be perfect in terms of provision of facilities, housing, commercial area and institutions. As mentioned earlier, happiness is subjective and people have different perceptions and ideas of what a perfect neighbourhood should embrace. Some would not like their houses to be near the playground although others see it as very convenient. In short, a neighbourhood can either bring positive or negative feelings to its residents. This is when the formula of happiness by Diener \& Biswas-Diener (2009) as provided earlier can be applied for neighbourhood environment:

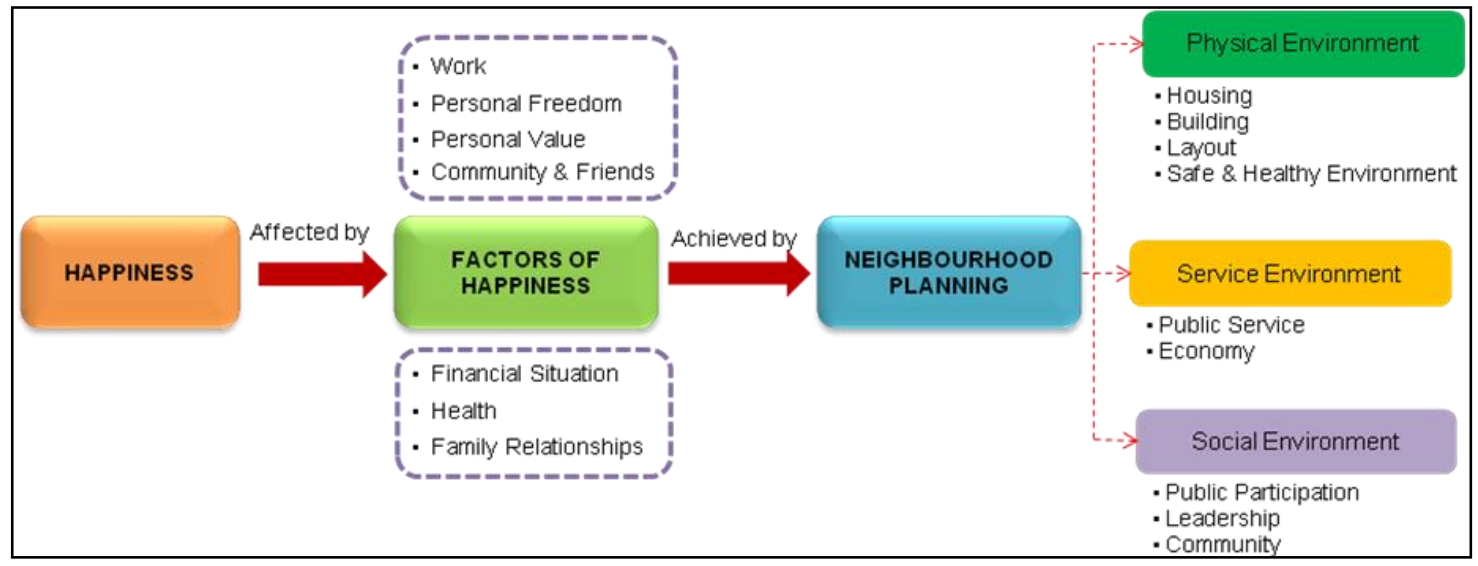

Fig. 1. The relationship of happiness and neighbourhood planning. Source: Adapted from Layard (2005) and Glanz \& C.Kegler (n.d.)

\section{The Current Practice of Encouraging Happiness in the Malaysian Neighbourhood}

In Malaysia, the MURNInets framework is an initiative to measure the sustainability of cities in Malaysia and is monitored under the Federal Department of Town and Country Planning. The framework incorporates Happiness Index Study, which consists of six dimensions. From this, 36 indicators were derived. In raising sustainable community, the Happiness Index evaluates "community vitality, cultural diversity and resilience, health, education, ecological diversity, quality of life and efficiency of governance" (Figure 2).

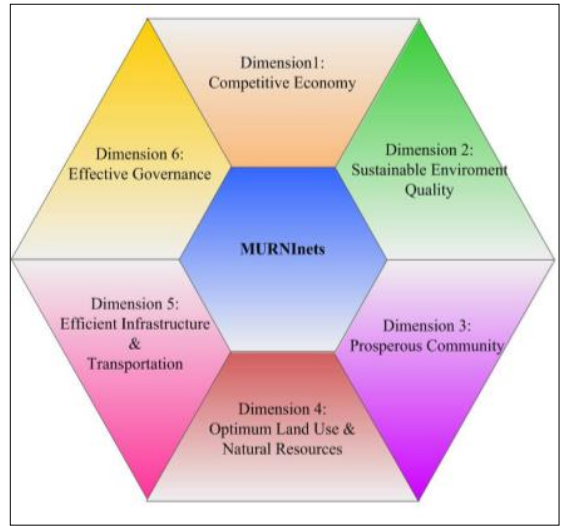

Fig. 2. MURNInets framework 


\section{Conclusion}

So far, the overview has seen an insight of the theory of happiness and its various beliefs and perceptions. Happiness is thought to be subjective therefore bringing numerous definitions and beliefs. Different philosophers have their own perception and understanding of happiness too. However, neighbourhood and happiness are believed to be linked together since happiness is influenced by the living environment and its components. Inevitably, there are many factors that affect the people's feeling and emotions. Apparently, a further question arises as to whether the elements for a sustainable community within the neighbourhood, as suggested, can stimulate happiness among the urban neighbourhood residents. This calls for a further investigation.

\section{Acknowledgments}

This research is supported by the UiTM Research Management Institute (RMI) and funded by the Malaysia's Ministry of Higher Education under the Research Acculturation Collaborative Effort (RACE) Grant (Project Code: 600-RMI/RACE 16/6/2 $(16 / 2013))$.

\section{References}

Bartolini, S., Bilancini, E. \& Pugno, M. (2013). Did the decline in social connections depress Americans' happiness? Social indicators research 110(3), 1033-1059

Becchetti, L., Pelloni, A., \& Rossetti, F. (2007). Sociability and happiness. Università di Roma Tor Vergat. Retrieved from http://www.aiccon.itffile/convdoc/n_44.pdf. Retrieved: June 2015.

Benharoon, Y. S. (2013). Building a Culture of peace in Muslim community in southern Thailand through family communication. Procedia-social and behavioral science, 91, 522-531. doi:http://dx.doi.org.ezaccess.library.uitm.edu.my/10.1016/j.sbspro.2013.08.450

Bergsma, A., Veenhoven, R., Have, M. ten., \& Ron de Graaf. (2010). Do they know how happy they are? On the value of self-rated happiness of people with a mental disorder. Journal of Happiness Studies, 12(5), 793-806. doi:10.1007/s10902-010-9227-5

Bernama. (2013). Malaysia needs happiness index, GDP index inadequate. The Star Online. Star Publications (M) Bhd. Available at: http://www.thestar.com.my/Business/Business-News/2013/09/06/Need-for-happiness-index-Ahmad-Husni-Gauge-will-cover-wider-aspects-ofwellbeing/?style=biz. Retrieved: June 2015.

Borrero, S., Escobar, A. B., Cortes, A. M., \& Maya, L. C. (2013). Poor and distressed, but happy: situational and cultural moderators of the relationship between wealth and happiness. Estudios Gerenciales, 29(126), 2-11. Brieger, W. R. (2006). Definitions of Community. Retrieved from http://ocw.jhsph.edu/courses/socialbehavioralfoundations/PDFs/Lecture10.pdf

Buijs, P. (2007). Dutch opinions on happiness during the enlightment 1658-1835. The Age of Happiness, (3), 51-62. Civilization. (n.d.). Retrieved May 27, 2015, from http://dictionary.reference.com/browse/civilization

Cox, E., Turley, A., Davies, B., \& Harrison, M. (2013). The condition of Britain. Love thy neighbourhood: People and place in social reform. IPPR North. Retrieved from http://www.ippr.org/assets/media/images/media/files/publication/2013/11/love-thy-neighbourhood_Nov2013_11478.pdf. Retrieved: June 2015.

DeFrain, J., Brand, G., Friesen, J., \& Swanson, D. (2008). Why families are so important? Retrieved from http://ianrpubs.unl.edu/live/g1890/build/g1890.pdf. Retrieved: March 2015.

Diener, E., \& Biswas-Diener, R. (2009). Epilogue: About the science of happiness. In Happiness (pp. 244-253). Blackwell Publishing Ltd. doi:10.1002/9781444305159.epil

Diener, E., Tay, L., \& Myers, D. G. (2011). The religion paradox: If religion makes people happy, why are so many dropping out? Journal of personality and social psychology, 101(6), 1278-1290.

Douglas, S. (2013). Being active linked to long-term happiness. Retrieved from http://www.runnersworld.com/health/being-active-linked-to-long-term-happiness. Retrieved: May 2015.

Florida, R., Mellander, C. \& Rentfrow, P.J. (2013). The happiness of cities. Regional Studies 47(4): 613-627

Frey, B.S., \& Stutzer, A. (2013). The use of happiness research for public policy. Social choice and welfare 38(4): 659-674

Frey, B. S., \& Stutzer, A. (1999). Maximising happiness? German economic review, 1(22), 145-167.

Gavin, J. H., \& Mason, R. O. (2004). The virtuous organization: The value of happiness in the workplace. Organizational Dynamics, 33(4), 379-392. doi:http://dx.doi.org/10.1016/j.orgdyn.2004.09.005

Green, L. W., \& Mercer, S. L. (2001). Can public health researchers and agencies reconcile the push from funding bodies and the pull from communities? American Journal of Public Health, 91(12), 1926-1943. doi:10.2105/AJPH.91.12.1929

Guoqing Zhang, \& Veenhoven, R. (2008). Ancient Chinese philosophical advice: can it help us find happiness today? Journal of Happiness Studies, 9(3), 425443. doi:10.1007/s10902-006-9037-y

Hamedi, D. A. (2013). Farabi's view on happiness. International journal of advanced research, 1(7), 474-478. 
Han, C. (2015). Explaining the subjective well-being of urban and rural Chinese: Income, personal concerns, and societal evaluations. Social science research, 49, 179-190.

Healthy Spaces and Place Manual. (2009). Kingston ACT: Planning Institute of Australia. Retrieved from http://www.healthyplaces.org.au/userfiles/file/HS\&P An overview.pdf. Retrieved: May 2015.

Helliwel, J., \& Putnam, R. . (2005). The social context of well-being. In F. Huppert, N. Baylis, \& B. Keverne (Eds.), The Science of Well-Being (pp. 434-459). New York: Oxford University Press.

Kenny, S. A. J. P. (2014). Aristotle. Encyclopaedia Britannica. Retrieved from http://academic.eb.com.ezaccess.library.uitm.edu.my/EBchecked/topic/34560/Aristotle. Retrieved: May 2015.

Kesebir, P., \& Diener, E. (2008). In pursuit of happiness: Empirical Answers to happiness to philosophical questions. Perspectives on psychological science, 3(2), $117-125$.

Layard, R. (2005). Happiness: Lessons from a new sceince. Retrieved from http://books.google.com.my/books?id=KUmbTWcTDKcC\&pg=PT24\&source=gbs_toc_r\&cad=4\#v=onepage\&q\&f=false. Retrieved: March 2015.

Lehrer, E. L. (2004). Religion as a determinant of economic and demographic behaviour in the United States. Population and development review, $30,707-726$.

Leyden, K. M., Goldberg, A., \& Michelbach, P. (2011). Understanding the Pursuit of happiness in ten major cities. Urban affairs review, 47(6), 861-888.

Macdonald, J. J. (2005). Environments for Health. London \& Sterling, VA: Earthscan.

Meenakshi. (2011). Neighborhood unit and its conceptualization in the contemporary urban context. Institute of Town Planners, India journal, $81-87$.

Moradi, M., Meshki, M., \& Jabbarzade, A. (2013). A study on relationship between income, health and family relationship and happiness. Management Science Letters, 3(4), 1287-1290. doi:10.5267/j.msl.2013.02.017

Omand, G. (2015, April 19). Experts resort to science studying communities' pursuit of happiness. Retrieved from http://www.thestar.com/news/canada/2015/04/19/experts-resort-to-science-studying-communities-pursuit-of-happiness.html. Retrieved: May 2015.

Ott, J. C. (2006). Review of Richard Layard's "Happiness; Lessons from a New Science". Journal of Happiness Studies. doi:DOI 10.1007/sl0902-005-0934-2

Pearson, A. L., Bentham, G., Day, P., \& Kingham, S. (2014). Associations Between neighbourhood characteristics and obesity and related behaviours among adult New Zealanders. BMC Public Health 2014, 14(553). doi:10.1186/1471-2458-14-553

Schroeder, T. (2006). Desire. Philosophy Compass, 1(6), 631-639. doi:10.1111/j.1747-9991.2006.00047.x

Seligman, M. E. P., \& Royzman, E. (2003). Happiness: The three traditional theories. Retrieved from https://www.authentichappiness.sas.upenn.edu/newsletters/authentichappiness/happiness. Retrieved: June 2015.

Snoep, L. (2008). Religiousness and happiness in three nations: a research note. Journal of Happiness Studies, 9(2), 207-211. doi:10.1007/s10902-007-9045-6

Spruk, R., \& Aleskandar Keseljevic. (2014). Institutional origins of subjective well-being: Estimating the effects of economic freedom on national happiness. Journal of Happiness Studies. doi:10.1007/s10902-015-9616-x

Tandoc, E.C. \& Takashi, B. (2013).The complex road to happiness: the influence of human development, a healthy environment and a free press. Social indicators research 113(1): 537-550

The Star (2013). Najib: Campaign to fight crime ensures people are free from fear. Retrieved from http://www.thestar.com.my/News/Nation/2013/06/09/Alloutfight-against-crime-PM-Campaign-to-ensure-the-people-are-free-from-fear/. Retrieved: March 2015.

Varelius, J. (2013). Objective Explanations of Individual Well-Being, 15-30. doi:10.1007/978-94-007-5702-8_2

Veenhoven, R. (2003). Hedonism and happiness. Journal of Happiness Studies, 4, 437-457. doi:10.1023/B:JOHS.0000005719.56211.fd

Veenhoven, R. (2007). Healthy happiness: effects of happiness on physical health and the consequences for preventive health care. Journal of Happiness Studies, 9(3), 449-469. doi:10.1007/s10902-006-9042-1

Veenhoven, R., \& Hagerty, M. (2006). Rising happiness in nations 1946-2004: A reply to Easterlin. Social indicators research, 79(3), 421-436. 